Ann. Parasitol. Hum. Comp., 1992, $67: \mathrm{n}^{\circ} 3,75-81$.

Mémoire.
Key-words: Opisthorchis. Haplorchis. Schistosoma. Fasciolopsis. Fasciola. Cercariae. Snails. Laos.

Mots-clés : Opisthorchis. Haplorchis. Schistosoma. Fasciolopsis. Fasciola. Cercaire. Gastropodes. Laos.

\title{
LARVAL STAGES OF MEDICALLY IMPORTANT FLUKES (TREMATODA) FROM VIENTIANE PROVINCE, LAOS. PART II. CERCARIAE
}

\author{
O. DITRICH, V. NAŠINCOVÁ, T. SCHOLZ, M. GIBODA
}

SUMMARY

The cercariae of five flukes, which are potential human parasites, Opisthorchis viverrini (family Opisthorchiidae), Haplorchis taichui (Heterophyidae), Schistosoma spindale (Schistosomatidae), Fasciolopsis buski, and Fasciola gigantica (Fasciolidae) were found in freshwater snails from Laos. The cercariae of the above species, recorded in Laos for the first time, are illustrated and their morphology is briefly described. The snail Helicorbis umbilicalis represents a new intermediate host of $F$. buski. The occurrence of medically important snails in the Vientiane province will also be discussed.

RÉsumé : Les stades larvaires de Distomes d'importance médicale dans la province de Vientiane, Laos. Deuxième partie : les cercaires.

Les cercaires de cinq espèces de Distomes (Trematoda) : Opisthorchis viverrini (Opisthorchiidae), Haplorchis taichui (Heterophyidae), Schistosoma spindale (Schistosomatidae), Fasciolopsis buski et Fascioia gigantica (Fasciolidae) ont été trouvées dans des Gastropodes du Laos. Ces cercaires trouvées au Laos pour la première fois sont décrites et dessinées. La Gastropode Helicorbis umbilicalis représente un nouveau hôte premier intermédiaire pour Fasciolopsis buski. L'apparition des Gastropodes d'importance médicale dans la province de Vientiane est aussi mentionnée.

\section{INTRODUCTION}

During the study on opisthorchiasis carried out in Laos in $1989^{1}$, snails and fish, potentially intermediate hosts of trematodes, were examined. The metacercariae found in fish have been described in the Part I (Scholz et al., 1991). This paper gives the results of a survey of cercariae of some medically important trematodes which have been found in snails.

\section{MATERIALS AND METHODS}

A total of 6520 water snails of 22 species and subspecies were examined for the presence of cercariae (Table I).

Snails were collected in the Vientiane province from the following localities (Table 1 shows the number of snails examined) : 1) Vientiane capital - drains collecting polluted water into Kua

\footnotetext{
${ }^{1}$ This study is a part of the project « Studies on epidemiology and morbidity of selected parasitic diseases in Laos " carried out on the basis of bilateral scientific-technical cooperation between Czechoslovakia and Laos.

Institute of Parasitology, Czechoslovak Academy of Sciences, Brani šovská 31, 37005 Ceské Budějovice, Czechoslovakia.

Accepté le : 4 février 1992.
}

Dinh swamp and Samgniekchinaimo swamp; 2) Vientiane municipality - artificial fish ponds in Nong Teng; 3) Vientiane suburbs - rice fields and their irrigation systems in Khamsavath, Dong Naxok, That Luang, Sikhay, Nong Sang Thoo, Kaoliao, Don Khoi, Bung Salakham drain; 4) Vientiane municipality (Chanthaboury district) - rice fields around Nong Ping; 5) Vientiane municipality - rice fields and their irrigation system near Thadeua; 6) Toulakhon district - rice fields around Ban Nanin near Ban Keun; 7) Keo-Oudom district - rice fields and their irrigation systems around the villages of Ban Phonmi, Phonsavath, and Naxon; 8) Keo-Oudom district - fish ponds near Ban Thinkeo; 9) Vientiane capital - the Mekong river; 10) Vientiane municipality the Khu Khana river (30 km NW to Vientiane); 11) the Nam Ngum river in village of Ban Nanin and district centre Thinkeo; 12) Nam Ngum water reservoir (18 localities, in detail listed in a paper by Ditrich et al., 1990). The number of snails does not reflect the actual occurrence within an individual species in a locality because bithyniid snails, which are potentially intermediate hosts of Opisthorchis viverrini, were predominately collected.

The snails were individually placed into test tubes. The shedding of the cercariae was stimulated by artificial light. All snails were dissected approximately $48 \mathrm{~h}$ after collection.

The cercariae were drawn alive and urea solution and neutral red were only used for highlighting the excretory system and penetration glands. The cercariae, fixed with a $4 \%$ hot formaldehyde solution, were measured. Thirty specimens of each species were measured and the average and standard deviations were counted. All measurements are given in $\mu \mathrm{m}$.

The cercariae used for scanning electron microscopical (SEM) study were fixed with a $4 \%$ glutaraldehyde solution in cacodylate 
TABLE I. - Survey of snails examined.

\begin{tabular}{|c|c|c|c|c|c|c|c|c|c|c|c|c|c|}
\hline Locality $\mathrm{N}^{0}$. & 1 & 2 & 3 & 4 & 5 & 6 & 7 & 8 & 9 & 10 & 11 & 12 & Tot \\
\hline \multicolumn{14}{|l|}{ Viviparidae } \\
\hline $\begin{array}{l}\text { Filopaludina } \\
\text { polygrana }\end{array}$ & 0 & 0 & 11 & 0 & 0 & 0 & 0 & 0 & 0 & 0 & 0 & 10 & \\
\hline Idioma & & & 11 & & & & & & & & & & \\
\hline $\begin{array}{l}\text { umbilicata } \\
\text { Trochotaia }\end{array}$ & 0 & 0 & 32 & 0 & 0 & 0 & 0 & 0 & 0 & 0 & 0 & 0 & 32 \\
\hline $\begin{array}{l}\text { trochoides } \\
\text { Ampullaridae } \\
\text { Pila }\end{array}$ & 0 & 0 & 20 & 0 & 0 & 8 & 4 & 5 & 0 & 0 & 0 & 15 & 52 \\
\hline $\begin{array}{l}\text { Pila } \\
\text { ampullacea } \\
\text { Pila }\end{array}$ & 0 & 0 & 4 & 0 & 0 & 4 & 0 & 0 & 0 & 0 & 0 & 0 & 8 \\
\hline $\begin{array}{l}\text { scutata } \\
\text { Pila }\end{array}$ & 0 & 0 & 10 & 0 & 0 & 5 & 6 & 0 & 0 & 0 & 0 & 0 & 21 \\
\hline $\begin{array}{l}\text { polita } \\
\text { Bithynidae }\end{array}$ & 0 & 0 & 22 & 0 & 8 & 0 & 0 & 0 & 0 & 0 & 0 & 0 & 30 \\
\hline $\begin{array}{l}\text { Bithynias. } \\
\text { siamensis } \\
\text { Bithynias. }\end{array}$ & 23 & 0 & 151 & 180 & 0 & 0 & 0 & 0 & 0 & 0 & 0 & 0 & 354 \\
\hline $\begin{array}{l}\text { goniomphailus } \\
\text { Bithynias. }\end{array}$ & 0 & 0 & 1811 & 0 & 48 & 0 & 47 & 0 & 0 & 0 & 0 & 2007 & 3913 \\
\hline $\begin{array}{l}\text { laevis } \\
\text { Hydrobioides }\end{array}$ & 0 & 0 & 159 & 0 & 0 & 0 & 0 & 0 & 0 & 0 & 0 & 0 & 159 \\
\hline $\begin{array}{l}\text { nassa } \\
\text { Thiaridae }\end{array}$ & 0 & 0 & 281 & 0 & 0 & 0 & 0 & 0 & 0 & 0 & 0 & 0 & 281 \\
\hline $\begin{array}{l}\text { Adamietta } \\
\text { housei }\end{array}$ & 0 & 0 & 0 & 0 & 0 & 0 & 1 & 0 & 0 & 0 & 0 & 0 & 1 \\
\hline $\begin{array}{l}\text { psacudosul cospira } \\
\text { Tarebia }\end{array}$ & 0 & 0 & 0 & 0 & 0 & 0 & 0 & 0 & 20 & 0 & 0 & 0 & 20 \\
\hline $\begin{array}{l}\text { granifera } \\
\text { Thiara }\end{array}$ & 0 & 0 & 0 & 0 & 0 & 0 & 0 & 0 & 0 & 0 & 212 & 100 & 312 \\
\hline $\begin{array}{l}\text { scabra } \\
\text { Melanoides }\end{array}$ & 0 & 0 & 0 & 0 & 0 & 0 & 0 & 0 & 0 & 0 & 62 & 0 & 62 \\
\hline $\begin{array}{l}\text { tuberculata } \\
\text { Bucciniidae }\end{array}$ & 0 & 0 & 17 & 18 & 0 & 0 & 3 & 0 & 21 & 10 & 0 & 0 & 69 \\
\hline $\begin{array}{l}\text { helena } \\
\text { Lymnaeidae }\end{array}$ & 0 & 0 & 0 & 0 & 0 & 0 & 0 & 0 & 0 & 0 & 6 & 0 & 6 \\
\hline $\begin{array}{l}\text { Radix a. } \\
\text { rubiginosa } \\
\text { Planorbidae }\end{array}$ & 15 & 20 & 261 & 19 & 0 & 12 & 12 & 14 & 0 & 0 & 0 & 20 & 373 \\
\hline $\begin{array}{l}\text { Camtoceras } \\
\text { jiraponi } \\
\text { Gyraulus }\end{array}$ & 35 & 0 & 0 & 0 & 0 & 0 & 0 & 0 & 0 & 0 & 0 & 0 & 35 \\
\hline $\begin{array}{l}\text { convexisculus } \\
\text { Helicorbis }\end{array}$ & 30 & 0 & 8 & 0 & 0 & 0 & 0 & 45 & 0 & 0 & 0 & 3 & 86 \\
\hline $\begin{array}{l}\text { umbilicalis } \\
\text { Indoplanorbis }\end{array}$ & 40 & 0 & 122 & 0 & 0 & 0 & 0 & 0 & 0 & 0 & 0 & 0 & 162 \\
\hline exustus & 0 & 40 & 334 & 12 & 28 & 6 & 12 & 8 & 0 & 0 & 0 & 35 & 475 \\
\hline Total & 143 & 60 & 3248 & 240 & 84 & 35 & 85 & 72 & 41 & 14 & 300 & 2198 & 6520 \\
\hline
\end{tabular}

buffer, dehydrated in alcohol series and acetone, dried in $\mathrm{CO}_{2}$ by the critical-point method, gold-coated, and examined in a Tesla BS 300 electron microscope.

\section{SURVEY OF CERCARIAE}

Opisthorchiidae Braun, 1901.

1 - Opisthorchis viverrini (PoIRIER, 1886) (Fig. 1A, B)

Description : Oculate, pleurolophocercous, pipe-form cercaria. Body length $178 \pm 16$, body width $67 \pm 11$. Tail length $390 \pm 48$, tail width $25 \pm 2$. Diameter of oral sucker $39 \pm 3$. Pharynx length $9 \pm 1$, width $7 \pm 1$.

Body covered with minute spines; nine anterior rows with larger spines. Three transversal rows of preoral spines situated on dorsal lip of oral sucker. Ten long cilia visible on each lateral margin of body. Tail provided with wide dorsoventral fin-fold, dorsally beginning at first third of tail length and ventrally terminating in middle of tail. Tegument of tail apparently transversaly striated on anterior third.

Oral sucker slightly subterminal, pharynx well visible, oesophagus and caeca not developed. Eyespots located anterolaterally to pharynx. Central part of body occupied by penetration glands (at least 5 pairs); their ducts in two bundles on each side. Cystogenous glands mainly in lateral regions. Ventral sucker underdeveloped, spherical in shape, with diameter $38 \pm 4$. Excretory vesicle thick-walled, cup-shaped, its diameter $53 \pm 12$; main collecting ducts divided into anterior and posterior branches at level of ventral sucker, flame cell formula $2[(3+3)+(3+3+3)]=30$. Brownish pigment scattered throughout lateral body fields.

Host: Bithynia siamensis goniomphalus, prevalence $0.6 \%$ (number of snails examined-see Table 1).

Localities: 3-Khamsavath, Nong Sang Thoo; 12-Nam Ngum water reservoir (3 localities).

Comments: Cercariae under study well correspond to those described by Wykoff et al., (1965).

Out of the potentional host snails carrying $O$. viverrini, the cercariae of this fluke were only found in Bithynia siamensis goniomphalus in the present study, whilst B. siamensis siamensis (354 specimens examined) and $B$. siamensis laevis $(159 \mathrm{spec}$.) were negative. However, Chanawong and Waikagul (1991) demonstrated that $B$. s. goniomphalus is 4-7 times less susceptible to $O$. viverrini infection than B. s. siamensis and B. funiculata. B. s. goniomphalus has been reported as the first intermediate host of this fluke in North Eastern Thailand (Brockelman et al., 1985). B. s. siamensis in Central Thailand (Upatham and Sukhapanth, 1980), and a related species, B. funiculata, in Northern Thailand (Upatham, 1988).

Whilst $B$. s. goniomphalus was collected mainly from rice fields, $B$. s. siamensis and $B$. s. laevis were found in their irrigation systems (channels and drains). In the Nam Ngum water reservoir only one bythiniid snail, $B$. s. goniomphalus, was recorded. In our opinion, the above mentioned subspecies of $B$. siamensis should be considered as ecolological forms of this snail species, similar to that suggested by Wykoff et al. (1965).

Snails of the genus Bithynia (subgenus Digoniostoma) have been reported as the exclusive first intermediate hosts of $O$. viverrini (SEAMEO-TROPMED technical group 1986). Bisseru and Chong (1968) described a cercaria, designated as $O$. viverrini, from spontaneously and experimentally infected thiarid snail, Melanoides tuberculata, in Malaysia. However, their species identification seems to be questionable. The tail of the cercaria, as represented by these authors, possesses a fin-fold beginning just in proximal part of the tail. This tail fin arrangement is more typical of heterophyid cercariae.

The occurrence of $O$. viverrini cercariae has been reported to exhibit a distinctly seasonal character (Wykoff et al., 1965). It is assumed that this seasonal variation is caused by the lack of water in the rice fields during the dry season. Our observations in rice fields around the Vientiane capital support this assumption: O. viverrini cercariae were recorded in Bithynia snails from these fields as late as at the end of August and in September, while the snails collected there in June and at the beginning of July gave a negative result.

In contrast to our findings in rice fields, the ecology of Bithynia snails living around Nam Ngum water reservoir seems to be quite different because snails can be active throughout the whole year there. It is very probable that cercarial development in that locality does not have a seasonal character (Ditrich et al., 1990).

FIGURE 1.

Fig. 1. - A : Opisthorchis viverrini (Poirier, 1886) - total view of cercaria. B: O. viverrini - lateral view of tail. $C:$ Haplorchis taichui (Nishigori, 1924) - total view of cercaria. D:H. taichui - lateral view of tail. 

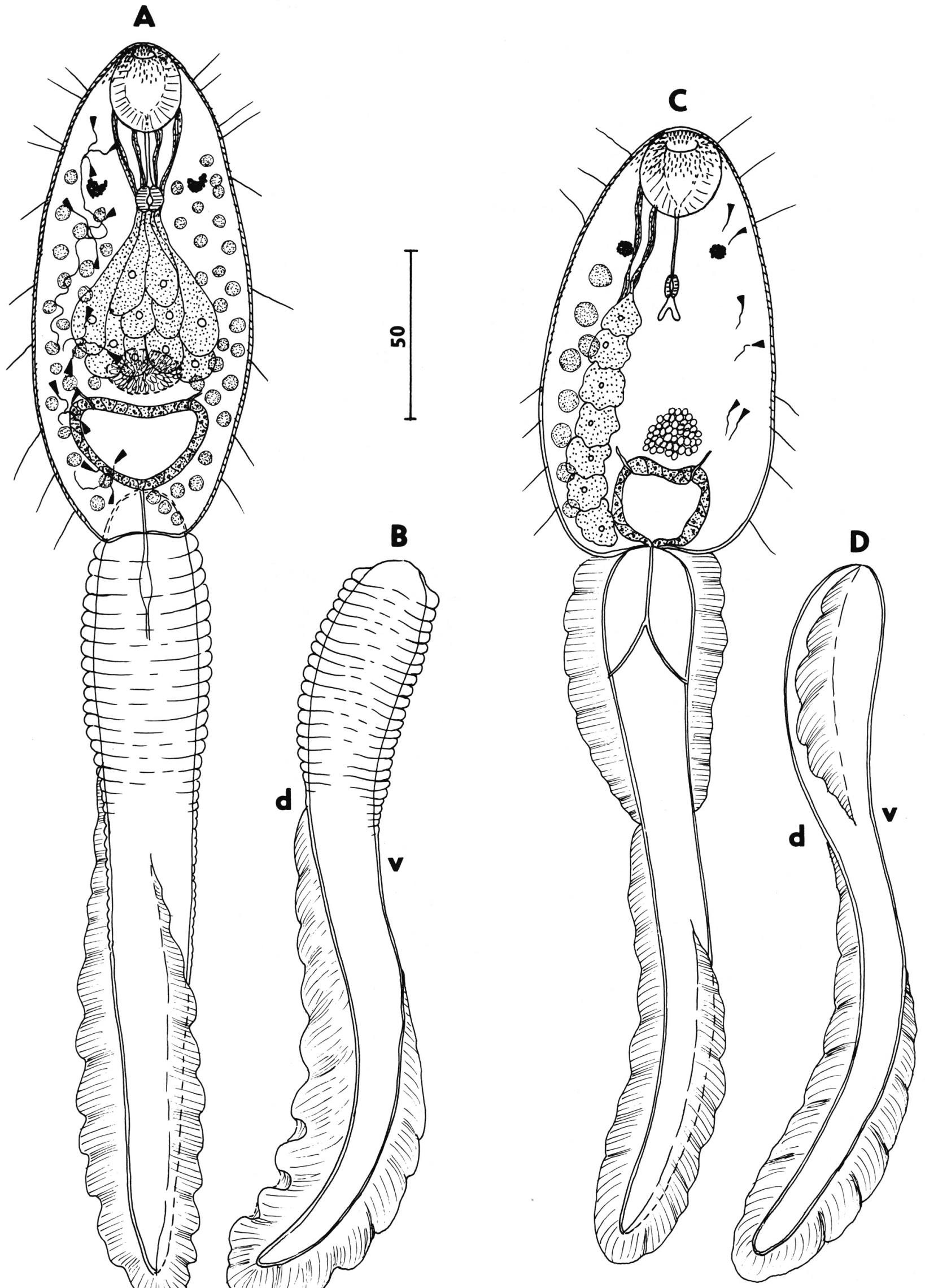

FIGURE 1. 
Heterophyidae Odhner, 1914.

2 - Haplorchis taichui (Nishigori, 1924) (Fig. 1C, D, Fig. 2)

Description: Oculate, pleurolophocercous, spade-shaped cercaria with slightly curved tail. Body length $138 \pm 18$, body width $56 \pm 9$. Tail length $335 \pm 52$, tail width $21 \pm 2$. Diameter of oral sucker $37 \pm 2$. Pharynx $7 \pm 1$ long and $4 \pm 1$ wide. Body surface covered with minute tegumental spines diminishing in size posteriorly. Dorsal lip of oral sucker bearing preoral spines arranged in three rows (Fig. 2A, B). At least 7 cilia located on both lateral margins of body; three anterior in front of eyespot, four posterior which are distinctly shorter, on hindbody. Tail with two lateral fin-folds in anterior third and dorsoventral fin-fold in other two posterior thirds (Fig. 2C). Oral opening subterminal, pharynx small, caeca rudimentary. Ventral sucker absent. Eyespots about half way between pharynx and oral sucker. Cystogenous glands with distinct nuclei in lateral fields of body, seven pairs of penetration glands in two longitudinal rows starting behind pharynx, reaching posteriorly to body extremity; their ducts in two bundles on each side. Flame cell formula not exactly determined (six pairs of flame cells observed); excretory vesicle round, its diameter $41 \pm 9$; tail excretory tubule bifurcating, opening on sides of tail at about one fifth of its length. Genital primordia situated in front of excretory vesicle.
Host: Tarebia granifera, prevalence $0.6 \%$.

Locality: 12) Nam Ngum water reservoir (1 locality).

Comments: The description of the cercaria corresponds with $\mathrm{H}$. taichui from Tarebia granifera found in Hawaii (Martin, 1958), with the exception of the flame cell formula. While the above author described 7 pairs of flame cells, we observed only six. However, flame cells localized in the hindbody of the cercariae studied were not clearly visible and the presence of a seventh pair cannot be excluded.

In addition to the cercariae, other developmental stages (metacercariae, adults) were found in the same locality of the Nam Ngum water reservoir (Ditrich et al., 1990). Human infection resulting from this trematode in the Vientiane province has also been confirmed (Giboda et al. 1991a).

The species Haplorchis taichui is a widely distributed parasite occurring in Hawaii, Iraq, India and Southeast Asia. Adults are localized in the intestine of fish-eating birds and mammals including man; metacercariae are found in freshwater fish (Pearson 1964, Pearson and Ow-Yang 1982). The cercariae of this species have hitherto been found in different species of thiarid snails (see Yamaguti, 1975).
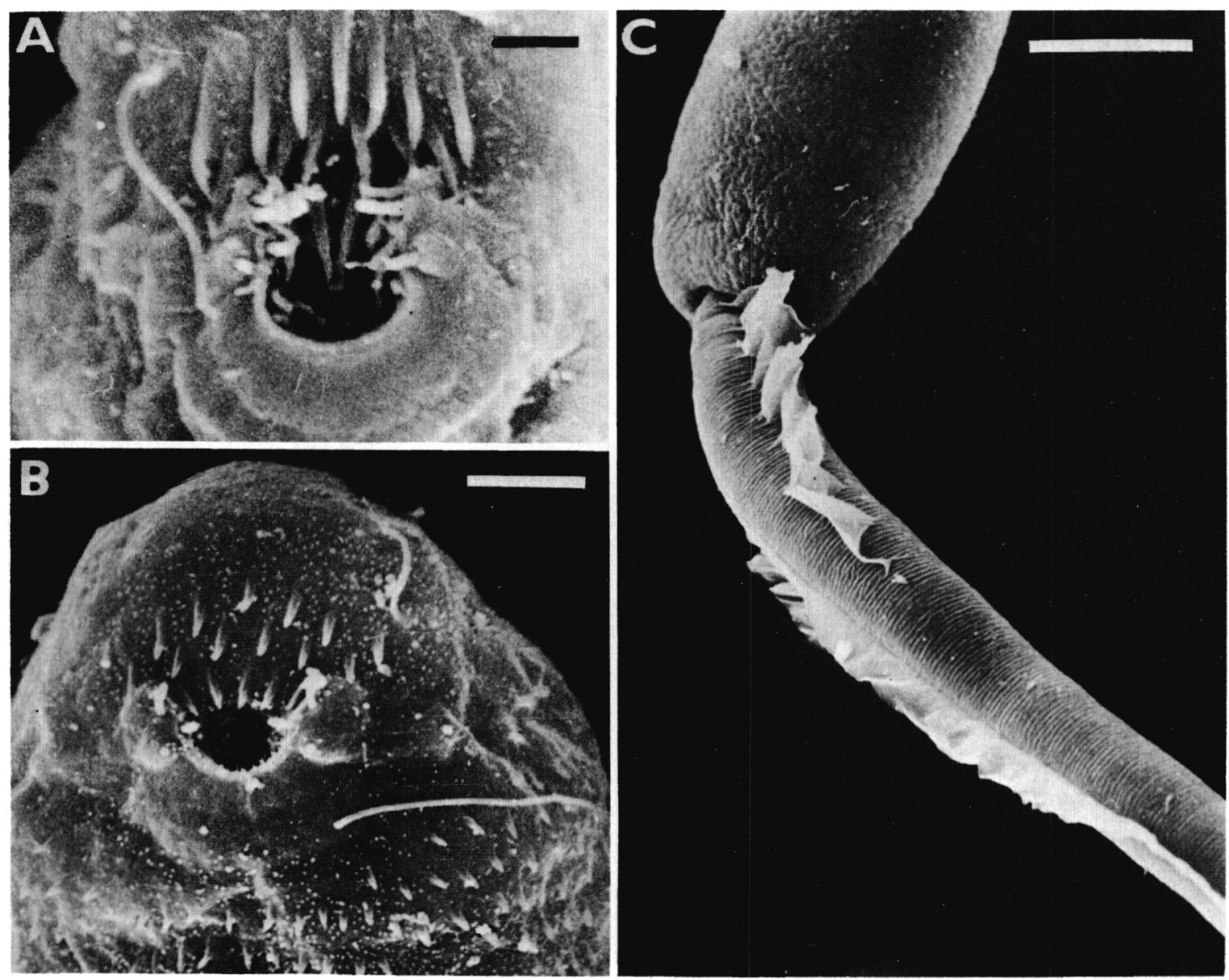

Fig. 2. - Haplorchis taichui - SEM photomicrograph of cercaria. $A$ : preoral spines, bar $=2 \mu \mathrm{m}$. $B:$ oral sucker, bar $=5 \mu \mathrm{m}$. $C$ : tail fin-fold, bar $=20 \mu \mathrm{m}$. 
$\mathbf{A}$

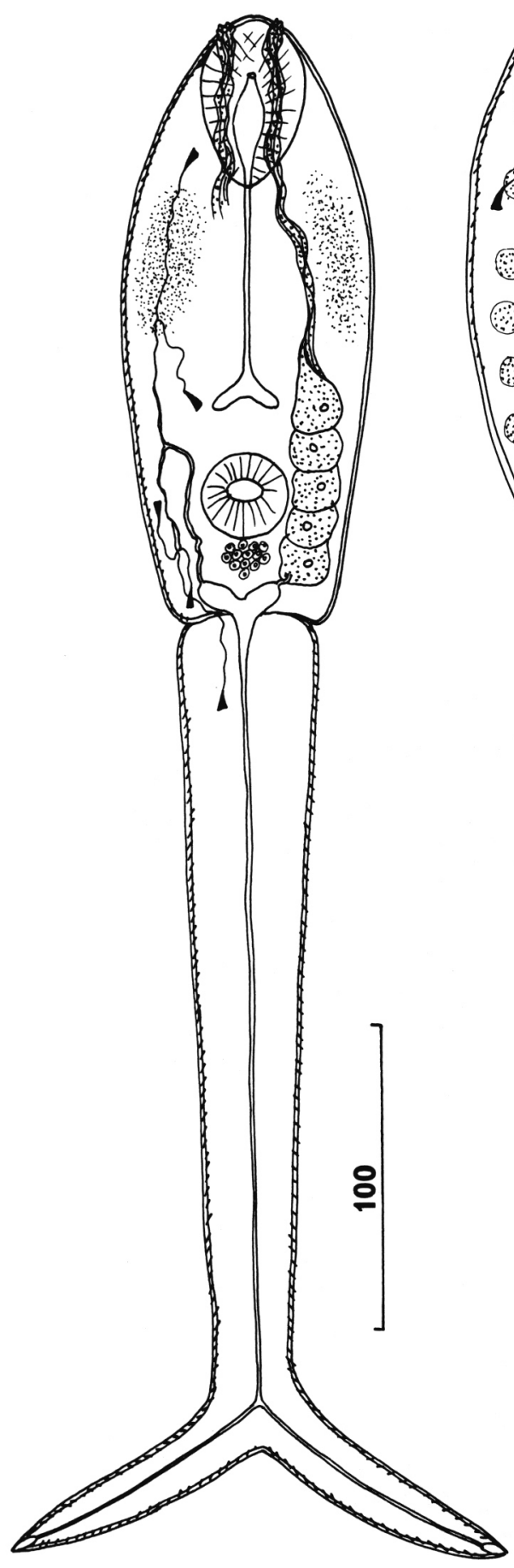

B

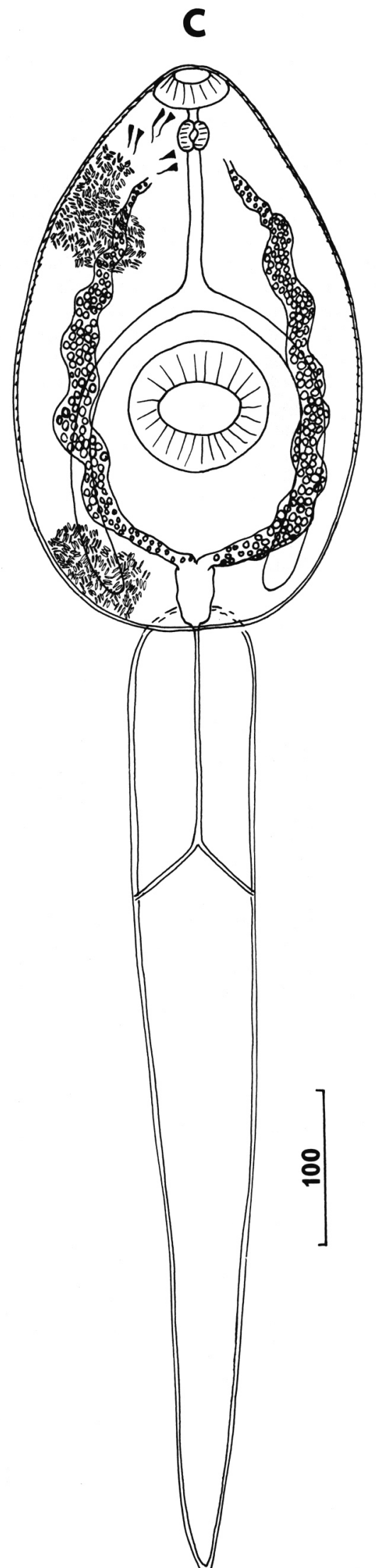

Fig. 3. - A : Schistosoma spindale Montgomery, 1906. B : Fasciolopsis buski (Lankester, 1857). C : Fasciola gigantica Cobbold, 1855. 
Schistosomatidae Poche, 1907.

3 - Schistosoma spindale (Montgomery, 1906) (Fig. 3A)

Description: Apharyngeal, brevifurcate cercariae. Body length $204 \pm 16$, width $63 \pm 9$. Tail stem length $287 \pm 28$, width $29 \pm 4$. Furca $111 \pm 21$ in length. Head organ pyriform in shape with strong muscular wall, its length $44 \pm 5$, width on anterior end $32 \pm 2$. Mouth on ventral side slightly behind anterior extremity. Oesophagus long, widened in its proximal part $(10 \pm 1)$, narrowing behind head organ, bifurcating into two short caeca at postequatorial level. Ventral sucker located at beginning of posterior fourth of body, its diameter $23 \pm 3$. Five pairs of penetration glands located laterally to ventral sucker; their ducts opening at anterior body end near large apical papillae. Excretory vesicle bicornuate; flame cell formula $2[2+2+(1)]=10$. Tail tubule bifurcating at distal end of tail stem, each branch opening at tip of furca. Genital primordia situated between ventral sucker and excretory vesicle.

Body, tail stem and furcae covered with minute tegumental spines.

Host: Indoplanorbis exustus, prevalence $0.2 \%$.

Locality: 6 (Ban Nanin).

Comments: The identification of the cercaria was not only based on its morphology but also the geographical distribution, the spectrum of snail intermediate hosts of Schistosoma species and findings of $S$. spindale eggs in the faeces from water buffaloes in the same locality were taken into consideration.

The planorbid snail, Indoplanorbis exustus, is a common intermediate host of this fluke in India, Sri Lanka, Indonesia, Malaysia, Thailand and Vietnam (Harinasuta et al., 1965; Rollinson and Southgate, 1987).

Schistosoma spindale, a parasite of cattle, goats and buffaloes, can produce cercarial dermatitis in humans (Palmieri et al., 1977). The inhabitants from the Vientiane province working in rice fields also suffer from dermatitis on their forearms. Indoplanorbis exustus snails are considered by these people as the causative agents of this itch.

Fasciolidae Railliet, 1895.

4 - Fasciolopsis buski (LANKESTER, 1857) (Fig. 3B)

Pigmentous, gymnocephalous cercaria. Body spinulate, tail glabrous. Body length $202 \pm 17$, width $116 \pm 19$. Tail length $426 \pm 23$, width $27 \pm 6$. Oral sucker diameter $38 \pm 3$, ventral sucker diameter $44 \pm 4$. Pharynx spherical with diameter $21 \pm 3$. Oesophagus bifurcating in middle of body, caeca reaching to its posterior end. Ventral sucker postequatorial. Excretory vesicle bicornuate; vesicle and main collecting ducts containing refractile concretions; flame cell formula not determined. Inner structures not clearly visible because of number of dark cystogenous glands under tegument.

Host: Helicorbis umbilicalis, prevalence $1.9 \%$.

Locality: 3 (Bung Salakham)

Comments: The cercaria corresponds in its shape with that of the Fasciolopsis buski as described by Barlow (1925). Moreover, the cercariae of $F$. buski have been found exclusively in planorbid snails, especially in members of the genera Planorbis and Segmentina (Yamaguti 1975, SEAMEO-TROPMED technical group 1986). Helicorbis umbilicalis represents a new intermediate host for this medically important trematode. F. buski seems to be rather common in the study area because its eggs were found in 0.9-3.8 \% of the inhabitants of the Vientiane province (Giboda et al., 1991b).

5 - Fasciola gigantica (СоввоLD, 1855) (Fig. 3C)

Pigmentous gymnocephalous cercaria. Body surface covered with minute spines. Body length $343 \pm 31$, width $276 \pm 12$. Tail length $598 \pm 32$, width $57 \pm 4$. Oral sucker diameter $45 \pm 6$, ventral sucker diameter $56 \pm 5$. Spherical pharynx $19 \pm 2$ in diameter. Oesophagus bifurcating in front of ventral sucker, caeca reaching posterior end of body. Numerous cystogenous glands containing rod-like bodies beneath tegument, making entire body opaque. Excretory vesicle elongate, main collecting ducts filled with refractile excretory granules; flame cell formula not determined, tail tubule bifurcating in first fourth of tail length.

Host: Radix auricularia rubiginosa, prevalence $0.5 \%$.

Locality: 4 (Nong Ping) and 6 (Ban Nanin)

Comments: The cercaria corresponds in its morphology with those described by Alicata (1938). The findings of $F$. gigantica eggs from stool samples of cattle and water buffaloes in localities 3, 6 and 8 support species identification.

The snail Radix auricularia rubiginosa (syn.: Lymnaea rubiginosa) is a common intermediate host of $F$. gigantica in Thailand (Dissamarn, 1955), Malaysia (Palmieri et al., 1977) and Indonesia (SEAMEO-TROPMED technical group 1986). In addition to the cercariae, the sporocysts and rediae of $F$. gigantica were seen in dissected snails. Our observations therefore support the opinion of Sullivan et al. (1976) about the presence of the sporocyst in the life cycle of $F$. gigantica. Ogambo-Ongoma and Goodman (1976) on the other hand reported the development without the mother sporocyst stage.

\section{DISCUSSION}

The examination of snails from the Vientiane province revealed the presence of the cercariae of five medically important flukes. From a medical point of view, the common occurrence of the Opisthorchis viverrini cercariae is the most significant. This fact accords with the data obtained during previous studies which revealed a relatively high prevalence of the $O$. viverrini infection in humans (Sornmani et al., 1977, Giboda et al., 1991a,b). The frequent occurrence of the first intermediate host of this fluke in the Vientiane province is also important from epidemiological point of view.

The study on fish-borne trematodoses carried out in Laos (Giboda et al., 1991a) revealed a simultaneous occurrence of heterophyid flukes and $O$. viverrini in both intermediate and definitive hosts. The combined task of distinguishing 
the eggs in human stool and determinating the metacercariae in fish is rather difficult and time consuming. On the other hand, the identification of cercariae - based on their morphology and the range of snail intermediate hosts can serve as a quick way of proving of the presence of $O$. viverrini in an area studied.

Out of 4 species of haplorchine flukes recorded in the Vientiane province (Ditrich et al., 1990, Scholz et al., 1991), only the cercariae of Haplorchis taichui were found. However, a relatively frequent occurrence of potential intermediate hosts (Melanoides tuberculata, Thiara scabra, Tarebia granifera) indicates that additional haplorchine cercariae may be found after a more extensive examination.

The occurrence of Fasciolopsis buski and Fasciola gigantica in rice fields and their irrigation systems is also of interest from an epidemiological point of view. Many species of plants growing there are eaten raw and people can easily acquire both parasites by ingestion of their adolescariae.

All species of cercariae have been recorded in snails from Laos for the first time. However, adult trematodes of Opisthorchis viverrini, Haplorchis taichui and Fasciolopsis buski have already been reported in humans (Segal et al., 1968, Sornmani et al., 1974, Giboda et al., 1991a).

Acknowledgments. - The authors are indebted to their Laotian colleagues, in particular to Drs. Khamliene Pholsena, Bouasy Hongvanthong and Bouaphanh Sayaseng for enabling this work and Mr. Boualy for valuable help in snail sampling. Thanks are due to Dr. Viroj Kitikoon, Mahidol University, Bangkok, Thailand, for enabling us to compare our snail samples from Laos with malacological collection of the University. Photomicrographs were made in the Laboratory of Electron Microscopy, Czechoslovak Academy of Sciences, České Budějovice.

\section{REFERENCES}

Alicata J. E. : Observation on the life history of Fasciola gigantica, the common liver fluke of cattle in Hawaii, and intermediate host, Fossaria ollula. Bull. Hawaii Agric. Exper. Stat., 1938, 80, 20 p. (Quoted after Yamaguti, 1975).

Barlow C. H. : The life cycle of the human intestinal fluke Fasciolopsis buski (Lankester). Am. J. Hyg. Monogr., 1925, ser. $\mathrm{n}^{\circ} 4,98 \mathrm{p}$. (Quoted after Yamaguti, 1975).

Chanawong A., Waikagul J. : Laboratory studies on host-parasite relationship of Bithynia snails and the liver fluke, Opisthorchis viverrini. SE. Asian J. Trop. Med. Publ. Hlth., 1991, 22, 235-239.

Dissamarn R. : The survey of liver fluke infection. J. Vet. Med. Assoc., 1955, 6, 64-78.

Ditrich O., Scholz T., Giboda M. : Occurrence of medically impor- tant flukes (Trematoda: Opisthorchiidae and Heterophyidae) in Nam Ngum water reservoir, Laos. SE. Asian J. Trop. Med. Publ. Hlth., 1990, 21, 482-488.

Giboda M., Ditrich O., Scholz T., Viengsay T., Bouaphanh S. : Human Opisthorchis and Haplorchis infections in Laos. Trans. Roy. Soc. Trop. Med. Hyg., 1991a, 85, 538-540.

Giboda M., Viengsay M., Bouaphan S., Ditrich O. : Épidémiologie des parasitoses intestinales au Laos (avec dosage des anticorps antiamibiens). Bull. Soc. Path. Ex., 1991b, 84, 184-193.

Harinasuta C., Kruatrachue M., Sornmani S. : A study of Schistosoma spindale in Thailand. J. Trop. Med. Hyg., 1965, 68, 125-127.

Martin W. E. : The life histories of some Hawaiian heterophyid trematodes. J. Parasitol., 1958, 44, 305-323.

Ogambo-Ongoma A. H., Goodman J. D. : Fasciola gigantica Cobbold 1856 in the snail. J. Parasitol., 1976, 62, 33-38.

Palmieri J. R., Sullivan J. T., Ow-Yang C. K. : A survey of snail hosts and larval trematodes collected in Peninsular Malaysia and Singapore from 1972 to 1977. SE. Asian J. Trop. Med. Publ. Hlth., 1977, 8, 275-277.

Pearson J. C. : A revision of the subfamily Haplorchinae Looss, 1899 (Trematoda: Heterophyidae). I. The Haplorchis group. Parasitology, 1964, 54, 601-676.

Pearson J. C., Ow-Yang C. K. : New species of Haplorchis from Southeast Asia, together with keys to the Haplorchis-group of heterophyid trematodes of the region. SE. Asian J. Trop. Med. Pub. Hlth., 1982, 13, 35-60.

Rollinson D., Southgate V. R. : The genus Schistosoma: A taxonomic appraisal. In: The Biology of Schistosomes. From Genes to Latrines (D. Rollinson and A. J. G. Simpson, eds.). Academic Press, London, pp. 1-49.

Scholz T., Ditrich O., Giboda M. : Larval stages of medically important flukes (Trematoda) from Vientiane province, Laos. Part. I. Metacercariae. Ann. Parasitol. Hum. Comp., 1991, 65 (year 1990, published in 1991), 238-243.

SEAMEO-TROPMED technical group : Snails of medical importance in Southeast Asia. SE. Asian J. Trop. Med. Publ. Hlth., $1986,17,282-322$.

Segal B., Humphrey J. M., Edwards S. J., Kirby M. D. : Parasites of man and domestic animals in Vietnam, Thailand, Laos, and Cambodia. Exp. Parasitol., 1968, 23, 412-464.

Sornmani S., Pathammavong O., Bunnag T., Impad P., Intarakhao C., Thirachantra S. : An epidemiological survey of human intestinal parasites in Vientiane, Laos. SE. Asian. J. Trop. Med. Publ. Hlth., 1977, 5, 541-546.

Sullivan J. T., Palmieri J. R., Ow-Yang C. K. : Occurrence of a sporocyst generation of Fasciola gigantica in the snail Lymnaea rubiginosa. SE. Asian J. Trop. Med. Publ. Hlth., 1977, 8, 133-134.

Upatham E. S. : A review of experimental and field research on the human liver fluke, Opisthorchis viverrini. J. Sci. Soc. Thailand, 1988, 14, 245-262.

Wykoff D. E., Harinasuta C., Juttijudata P., Winn M. M. : Opisthorchis viverrini in Thailand, the life cycle and comparison with O. felineus. J. Parasitol., 1965, 51, 207-214.

Yamaguti S. : A synoptical review of life histories of digenetic trematodes of vertebrates. Kagan Publ. Co., Tokyo, 1975, 590 pp. + 219 Plts. 